\title{
Off-Grid Electrification and its Impacts on the Waste Management System - the Case of Bangladesh
}

\author{
Alexander Batteiger \\ Postgraduate Program Microenergy-Systems \\ Technische Universität Berlin - Center for Technology and Society, Germany
}

\begin{abstract}
By the end of 2010 more than 1.6 billion people lacked access to modern energy services. To overcome this situation the United Nations started the "sustainable energy for all initiative" with the objective to provide access to modern energy services for all until 2030. Especially for off-grid areas in the least developed countries decentralized systems based on renewable energies and in particular solar energy are seen as the most promising solution for electrification. Lack of access to modern energy services goes in general along with a lack of a proper waste management system for the expected future waste electrical and electronic equipment (WEEE). The main lessons learned from a waste management perspective, is that prequalification of the suppliers can change industry standards. Local battery producers and recyclers and a working collection system are needed to guarantee that lead acid batteries are recycled properly.
\end{abstract}

Keywords: Rural Electrification, Waste Management, Solar Home System, Battery Recycling, Microenergy System, Bangladesh, Least Developed Countries

\section{INTRODUCTION}

By the end of 2010 more than 1.6 billion people lacked access to modern energy services. To overcome this situation the United Nations started the "sustainable energy for all initiative" with the objective to provide access to modern energy services for all until 2030. Especially for off-grid areas in the least developed countries decentralized systems based on renewable energies and in particular solar energy are seen as the most promising solution to electrify regions ${ }^{1}$. Lack of access to modern energy services goes in general along with a lack of proper waste management systems for the expected future waste electrical and electronic equipment (WEEE). The "Rural Electrification and Renewable Energy Development Project (REREDP)" in Bangladesh is one of the most successful rural electrification programs in world. The REREDP can and will draw important lessons for upcoming off-grid electrification projects in other regions of the world.

IRENA (2014). International Renewable Energy Agency. REthinking Energy 2014 - Towards a new power system. http://www. irena.org/rethinking/ [Last accessed 10th of September 2014] 


\section{REGIONAL BACKGROUND AND THE CASE OF THE RENEWABLE ENERGY DEVELOPMENT PROJECT}

The REREDP I of Bangladesh started back in 2002. The second round of the REREDP was launched in 2012. In 2002 microfinance organizations had already spread throughout Bangladesh and Solar Home Systems (SHS) for the electrification of rural households were distributed in combination with microfinance. The SHS are sold to the end users by so called Partner Organizations (PO), which provide microcredits as well as the maintenance of the SHS. The POs receive financial support from the Infrastructure and Development Company Limited (IDCOL) while IDCOL receives financial support for the REREDP from the Worldbank, KfW and the Asian Development Bank among others ${ }^{2}$.

The standard configuration nowadays for a SHS in rural areas is a $35 \mathrm{~W}_{\mathrm{p}}$ solar panel, a charge controller and a lead-acid battery with a capacity of 50Ah. A SHS supplies enough energy to the household to use a television, six LED-lights, a fan and mobile phone charging. The yearly installation rate of Solar Home Systems under the REREDP was at the beginning comparatively low. In 2008 the program started to grew rapidly with a total yearly installation of about 100.000. Within four years the yearly installations grew to $600.000 \mathrm{SHS}$ in $2012^{3}$. In total more than 2.7 Million SHS were installed under the REREDP by the end of 2013 and SHS are close to become economical viable without subsidies. With an average household size of 5 persons almost 14 million Bangladeshi already directly benefit from the REREDP electrifying about 10\% of the total population. To fulfill the goal of 6 Million SHS by the end of 2016 yearly installation rates have to exceed one million SHS. In Addition to the SHS goals until 2016 a total number of 50 solar minigrids and 1550 solar irrigation pumps will be installed according to IDCOL 4 .

According to the Blacksmith Institute which published in cooperation with the Green Cross a report, lead pollution is among the six worst pollution a problems of the world 5 . In low- and middle-income countries car battery recycling is one of the main sources of lead pollution ${ }^{6}$. About three quarter of all lead is used for batteries ${ }^{7}$. In Bangladesh SolarBatteries already have a market share of about 25\% (Total market size around 2.5 million lead-acid batteries) and the share is rapidly growing. Photovoltaic energy systems are already identified to contribute significantly to lead pollution in China and India among other countries ${ }^{8}$. Depending on the recycling facilities and technologies the lead losses over the life time vary between $5 \%$ in countries with advanced infrastructure and $50 \%$ only in the recycling phase in the informal sector? ${ }^{9}$.

Based on historical installation rates of SHS between 800.000 and 1.2 million lead-acid solar batteries equaling an total amount of approximately 6.000 to 8.000 metric tons of lead will enter the waste management system of Bangladesh in $2016^{10}$. A research conducted by Waste Concern in 2006 showed that the recycling capacity for lead of the formal sector was only 3.000 metric tons per year ${ }^{11}$ and reached nowadays almost 15.000 metric tons per year ${ }^{12}$. Therefore the impact of the REREDP on the battery industry and especially on the waste management system can already be observed. According to that, the question has to be raised how future infrastructure programs for rural electrification in developing countries can address environmental impacts due to improper recycling and recycling facilities in advance and how it should be integrated into the project design. Since Bangladesh has a very successful

2 Sadeque, Z., Rysankova, D., Elahi, R., Soni, R., 2014. Scaling Up Access to Electricity: The Case of Bangladesh, Live Wire: A knowledge note series for the energy practice. World Bank Group

3 World Bank (2013a). Implementation Completion and Results Report. Rural Electrification and Renewable Energy Development Project. The World Bank. http://www-wds.worldbank.org/. [Last accessed 20th of January 2014].

4 IDCOL (2014a). Renewable Energy Projects. http://idcol.org/energyProject.php. [Last accessed 20th of January 2014].

5 Blacksmith Institute (2010). World's Worst Pollution Problems Report 2010. Blacksmith Institute, www.worstpolluted.org/files/ FileUpload/files/2010/WWPP-2010-Report-Web.pdf. [Last accessed 08th of January 2014].

6 Blacksmith Institute (2010), World's Worst Pollution Prolems.

7 Roberts, H. (2003). Changing Patterns in Global Lead Supply and Demand. Journal of Power Sources 116 (1-2): 23-31. doi:10.1016/ S0378-7753(02)00701-2.

8 Gottesfeld, P. and Cherry, C. (2011). Lead Emissions from Solar Photovoltaic Energy Systems in China and India. Energy Policy 39 (9): 4939-46. doi:10.1016/j.enpol.2011.06.021.

9 Hoffmann, U, and B Wilson. (2000). Requirements For, and Benefits Of, Environmentally Sound and Economically Viable Management of Battery Recycling in the Philippines in the Wake of Basel Convention Trade Restrictions. Journal of Power Sources 88 (1): $115-23$. doi:10.1016/S0378-7753(99)00519-4.

10 Batteiger, A. (2014). Towards a waste management System, Innovating Energy Access for Remote Areas: Discovering untapped resources, University of California: Symposium 10.-12.04.2014 (forthcoming).

11 Waste Concern (2006). Lead Acid Battery Recycling in Bangladesh. http://www.wasteconcern.org/Publication/ BatteryRecyclingBroFinal.pdf. [Last accessed 14th of January 2014].

12 IDCOL (2014b). ISO 14001:2004 and OHSAS 18001:2007 Compliance Status Report of Battery Suppliers and Recyclers of IDCOL SHS Program, http://www.idcol.org/download/5d86a0e52ea14328b0e421c1c9504594.pdf [Last accessed 18th of June 2014] 
rural electrification program, the case and lessons learned out of a waste management perspective of Bangladesh are presented. The main objective of this research is how energy access for all can go along with a proper treatment of the resulting WEEE, especially for lead-acid batteries and how the REREDP influenced the battery industry in Bangladesh.

\section{METHODOLOGY}

An intensive literature review on recycling of SHS, lead-acid batteries and the recycling sector in developing countries and with a special focus on Bangladesh and the REREDP I and II was conducted. Out of the literature review a waste estimation model was developed and described ${ }^{13}$. In a field research in Bangladesh semi-structured interviews with representatives of the four biggest lead-acid battery producers and recyclers representing over $80 \%$ of the market and $100 \%$ of the exports were conducted. Two lead-acid battery factories with recycling facilities of the formal sector as well as two facilities of the informal sector were visited.

\section{RESULTS}

In the beginning of the first round of the REREDP in 2002 no environmental impacts other than $\mathrm{CO}_{2}$-Mitigation were assessed by the involved institutions ${ }^{14}$. The REREDP was in 2002 planned to be a 50 Million USD project. Due to its success, international support for the program soon began to rise and environmental impacts became visible. In 2005 IDCOL developed a policy guideline on the disposal of warranty expired batteries. Costumers should be notified three months before the warranty of five years expires to change their batteries ${ }^{15}$. In 2006 the Department of Environment of Bangladesh added an amendment to the Environmental Protection Act of 1995, which regulated the battery recycling and collection ${ }^{16}$. In 2006 the recycling of solar batteries had no basically no impact on the regulation. Nevertheless, in the national 3R Strategy (Reduce, Reuse, Recycle) in 2010 it was stated that the Solar Home System Program has a growing impact on the recycling of lead-acid batteries ${ }^{17}$. In the final report of the World Bank of the first round of the REREDP it was stated that the project helped to increase standards in battery recycling. In 2012 the second round of the project was launched, since than regular assessments of environmental impacts have to be reported ${ }^{18}$. In the first environmental and social impact report of IDCOL, two major environmental impacts related to the SHS-Project were reported: Improper disposal of lead-acid batteries (LABs) and solar panels ${ }^{19}$. Bye the end of 2013 all battery producers of Bangladesh were ISO 14001 (Environmental Management Standard) and OHSAS 18001:2007 (Occupational Health Safety Standard) certified ${ }^{20}$. IDCOL has forced its suppliers to establish standards due to the pressure of the developing organizations.

The results of the interviews with the four biggest battery producers of Bangladesh show, that they follow the ISO standard because of the REREDP. All the battery producers expect future sales of solar batteries in Bangladesh to grow and hope to export more. The biggest of the four producers already started to export solar batteries to more than 50 countries in the world. The strategy of the lead recycling and lead usage differs between the battery producers. There is one producer using 100\% recycled local lead out of the company owned recycling facility, while two producers answered that they do not use recycled lead. The fourth answered, that they use a bit less than $20 \%$ of recycled lead, but the prize of the scrap-lead in the market is too high to recycle with proper and environmental sound technology. According to the two visited battery recyclers of the informal sector the market is still growing. Even though that due to the regulations by IDCOL none of the solar-batteries should be recycled in the informal

13 Batteiger (2014), Towards a Waste Management System for SHS in Bangladesh.

14 World Bank (2013a), Implementation Completion and Results Report.

15,19 IDCOL (2013). Environmental and social management framework. Infrastructure Development Company Limited, Dhaka. http:// www.idcol.org/Download/Harmonised\%20ESMF\%202013.pdf. [Last accessed 14th of January 2014].

16,17 DOE (2010). National 3R Strategy for Waste Management. Department of Environment. Minstery of Enivironent and Forests. Government of the People's Republic of Bangladesh. Dhaka.

18 WB (2013b). Project Appraisal Document: Rural Electrification and Renewable Energy Development II (REREDII) Project. World Bank. http://www-wds.worldbank.org/. [Last accessed 18th of January 2014].

20 IDCOL 2014b, ISO 14001:2004 and OHSAS 18001:2007. 
sector $^{21}$. Especially in rural areas lead-acid batteries are mostly recycled in the informal sector. The reason for that seems to be, that costumers trust the local recyclers more than the collection framework of the Partner Organizations (PO) and after the warranty time of 5 years the POs lose their interest in maintaining the contact with the costumers ${ }^{22}$.

All the battery producers stated that the collection system of used lead-acid batteries needs to be improved, since not enough used lead-acid batteries enter the system. In the "Environmental and Social Management Framework" of IDCOL it is stated that none of the battery recyclers is collecting the batteries with the acids. This mainly happens because of cost savings due to lower weight of the batteries. According to the report "the electrolyte is poured here and there" 23 . The visited battery recycling plants of the battery producers had a high standard. In both factories air treatment and waste water treatment facilities were in use. The complete recycling process was done indoors and nearly all of the workers were wearing breathing protection.

\section{DISCUSSION}

The case of SHS program under the REREDP shows how rural electrification influence supplying industries. As all international organizations started to ask for environmental impact reports, IDCOL was forced to change the prequalification of the battery suppliers ${ }^{24}$. Solar batteries have a market share of only $25 \%$ in the Bangladeshi battery market, but changed the complete industry due to the implementation of international standards. Therefore one of the lessons learned is, that prequalification in rural electrification projects can force an industry to change towards more ecological sound producing and recycling. Another important factor of the battery recycling is the existence of local battery factories and therefore formal local lead recyclers, since this is the only way to guaranty that high quantities of the used lead-acid batteries enter the formal recycling sector. For minimizing the environmental impacts of rural electrification programs based on solar energies it is key to think about working waste collection systems, since lead losses in the informal sector can be as high as 50\% only in the recycling phase. Especially for the collection of the uses lead-acid batteries with the acids or a local acid treatment of the acid, new concepts need to be developed.

\section{ACKNOWLEDGEMENT}

The authors gratefully acknowledge the Hans-Böckler Foundation for funding the postgraduate program microenergy-systems at Technische Universität Berlin and this doctoral thesis.

21,24 IDCOL (2014a), Renewable Energy Projects.

22 Brossmann, M. (2013). Off-Grid Rural Electrification and Fighting Poverty. Master Thesis, University of Tübingen.

23 IDCOL (2013), Environmental and Social Management Framework. 